\title{
PHILOSOPHY AND TECHNOLOGY
}

\section{Edited by Roger Fellows}

\section{Contributors}

Renford Bambrough, Sophie Botros, Nancy Cartwright, Stephen R. L. Clark David E. Cooper, Roger Fellows, Robert Grant, Kwame Gyekye, Willem Hackmann, Robin Findlay Hendry, Anthony O'Hear, Michael Smithurst 


\section{Philosophy and}

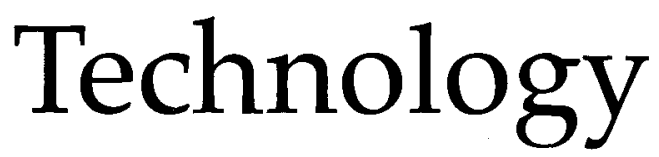

ROYAL INSTITUTE OF PHILOSOPHY SUPPLEMENT: 38

EDITED BY

Roger Fellows 
Published by the Press Syndicate of the University of Cambridge The Pitt Building, Trumpington Street, Cambridge, CB2 1RP

40 West 20th Street, New York, NY 10011-4211, USA

10 Stamford Road, Oakleigh, Melbourne 3166, Australia

(C) The Royal Institute of Philosophy and the contributors 1995

A catalogue record for this book is available from the British Library

\section{Library of Congress Cataloguing in Publication Data}

Philosophy and technology/edited by Roger Fellows

p. cm.-(Royal Institute of Philosophy supplement: 38)

1. Technology-Philosophy. I. Fellows, Roger. II. Series T14.P497 1995

$601-\mathrm{dc} 20$

ISBN 0521558166 


\section{Contents}

Introduction 1

ROGER FELLOWS

Technology: Liberation or Enslavement?

DAVID E. COOPER

Do the Successes of Technology Evidence the Truth of Theories

MICHAEL SMITHURST

Instrument and Reality: The Case of Terrestrial Magnetism and the Northern Lights (Aurora Borealis) WILLEM HACKMANN

Realism and Progress: Why Scientists should be Realists ROBIN FINLAY HENDRY

Quantum Technology: Where to Look for the Quantum Measurement Problem NANCY CARTWRIGHT

Welcome to Wales: Searle on the Computational Theory of Mind

ROGER FELLOWS

Acts, Omissions and Keeping Patients Alive in a Persistent Vegetative State SOPHIE BOTROS

Technology and Culture in a Developing Country KWAME GYEKYE

Art and Technology: An Old Tension ANTHONY O'HEAR

Tools, Machines and Marvels STEPHEN R. L. CLARK

Values, Means and Ends 


\section{Contents}

Question Time

189

RENFORD BAMBROUGH

Notes on Contributors

202

Index of Names

204 